\title{
When a drug does more than it needs: angio-oedema, an important adverse effect
}

\author{
Maria Betânia Ferreira, Sara M Rocha, José Miguel Maia, João Neves
}

Department of Internal Medicine, Centro Hospitalar Porto, Porto, Portugal

\section{Correspondence to} Dr Maria Betânia Ferreira, betania_ferreira82@hotmail. com

Accepted 3 February 2014

\section{DESCRIPTION}

A 77 -year-old man, with a history of arterial hypertension, hypercholesterolaemia and obesity, presented to our emergency department with acute swelling of the tongue. He was being treated with an ACE inhibitor and a statin for the past few years and had been tolerating both well. He denied cutaneous or abdominal symptoms but admitted to having had a similar but milder episode 4 months earlier, which was treated with corticosteroids and antihistaminic drugs. On examination, massive swelling of the tongue outside the mouth was evident (figure 1), without any signs of airway obstruction. He was started on intravenous glucocorticoids, antihistaminic drugs and intramuscular epinephrine; simultaneously, the surgical department was called in the event and an emergent tracheotomy was required. Continuous monitoring was provided and no significant improvement was seen in the first $12 \mathrm{~h}$. However, tongue swelling resolved over the next $24 \mathrm{~h}$ and he was discharged home with discontinuation of the ACE inhibitor. Two weeks later, he was completely asymptomatic (figure 2). The measurement of C1 inhibitor level was in the normal range, supporting the diagnosis of angio-oedema induced by ACE inhibitor. After a year of follow-up, no other events were reported.

This case report emphasises potentially lifethreatening angio-oedema of ACE inhibitors, which

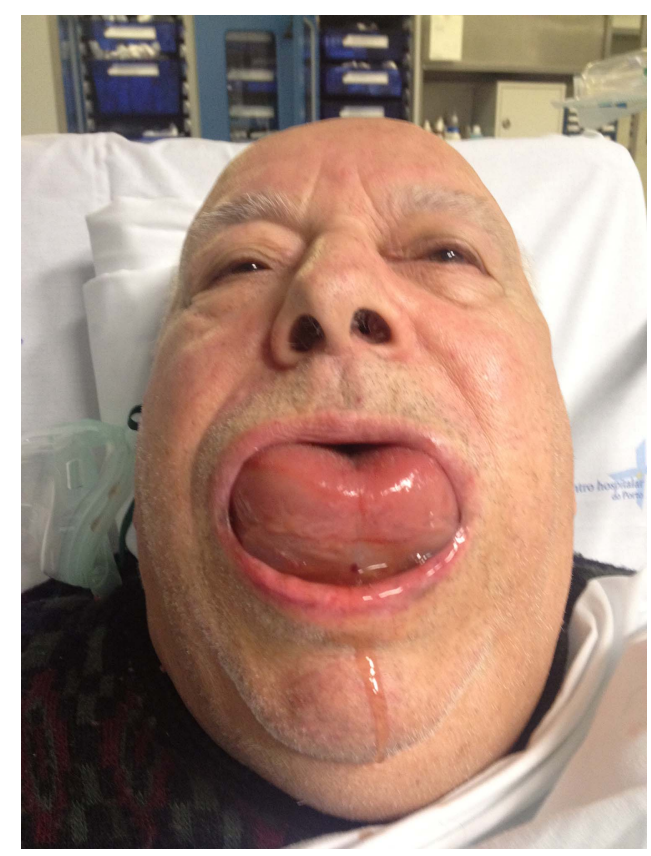

Figure 1 A massive tongue swelling outside the mouth was evident in the admission, $4 \mathrm{~h}$ after intake of ACE inhibitor.

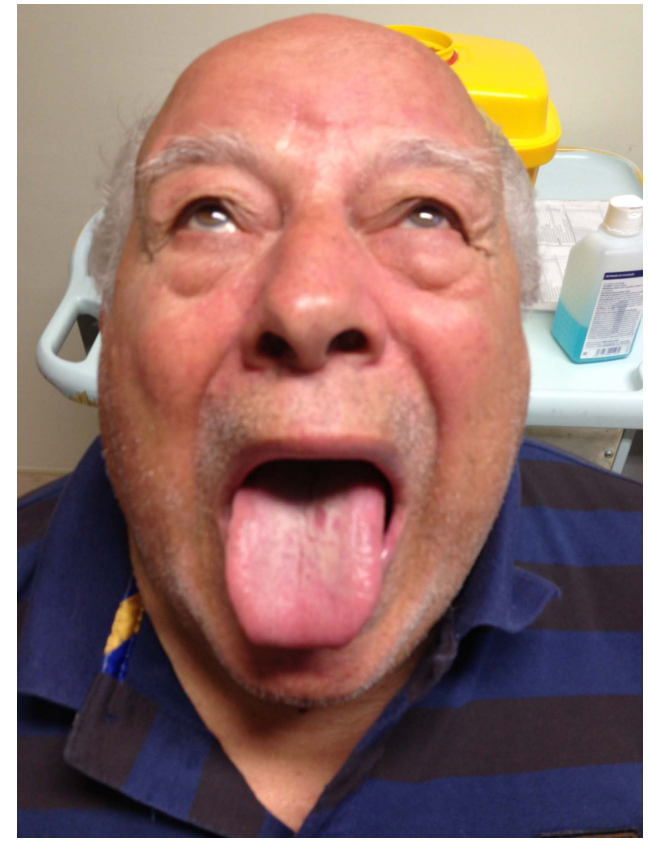

Figure 2 Two weeks later, the patient was completely asymptomatic.

are one of the most used drug classes, occurring between $0.1 \%$ and $0.5 \%$ of patients taking these drugs. ${ }^{1}$ This event most commonly affects the lips, tongue, face and upper airway, which may progress to airway obstruction in up to $10 \%$ of cases; rarely, massive tongue swelling and asphyxiation can occur. $^{12}$

\section{Learning points}

- Angio-oedema is a potential side effect of many drugs, particularly ACE inhibitors, bupropion, non-steroidal anti-inflammatory drugs and antidepressants.

- ACE inhibitors are the leading cause of angiooedema; although more than one-half of the cases occur during the first week of exposure, it may occur any time during the course of therapy, from a few hours to many years of treatment. $^{12}$

- The primary treatment of ACE inhibitor-induced angio-oedema is drug discontinuation; other treatments (such as antihistaminic drugs, glucocorticoids and epinephrine) have no clear evidence in this bradykinin-mediated disease. If the drug is not discontinued, the acute episode will still resolve, but future episodes will be more serious and frequent. ${ }^{23}$ 


\section{Competing interests None.}

Patient consent Obtained.

Provenance and peer review Not commissioned; externally peer reviewed.

\section{REFERENCES}

1 Messerli FH, Nussburger J. Vasopeptidase inhibition and angioedema. Lancet 2000;356:608-9.
2 Grant NN, Deeb ZE, Chia SH. Clinical experience with angiotensin-converting enzyme inhibitor-induced angioedema. Otolaryngol Head Neck Surg 2007:137:931-5.

3 Beltrami L, Zingale LC, Carugo S, et al. Angiotensin-converting enzyme inhibitor related angioedema: how to deal with it. Expert Opin Drug Saf 2006;5:643-9.

Copyright 2014 BMJ Publishing Group. All rights reserved. For permission to reuse any of this content visit http://group.bmj.com/group/rights-licensing/permissions.

BMJ Case Report Fellows may re-use this article for personal use and teaching without any further permission.

Become a Fellow of BMJ Case Reports today and you can:

- Submit as many cases as you like

- Enjoy fast sympathetic peer review and rapid publication of accepted articles

- Access all the published articles

- Re-use any of the published material for personal use and teaching without further permission

For information on Institutional Fellowships contact consortiasales@bmjgroup.com

Visit casereports.bmj.com for more articles like this and to become a Fellow 